\title{
Impact and Seasonal Variability of Faecal Indicators Bacteria Contamination in Downstream Part of Comoe River and Its Two Tributaries (Côte d'Ivoire)
}

\author{
Kouamé Cyr-Kevin Yao ${ }^{1 *}$, Ouattara Koffi Nouho", Achiépo Odilon Yapo Mélaine ${ }^{2}$ and \\ Ouattara Allassane ${ }^{1}$
}

\author{
${ }^{1}$ Laboratoire Pôle de Recherche Pêche et Aquaculture, UFR-SGE, Université Nangui \\ Abrogoua, 02 BP 801 Abidjan 02, Côte d'Ivoire \\ ${ }^{2}$ Laboratoire d'Ingénierie des Données et d'Intelligence Artificielle, INSIA, 09 BP 4037 \\ Abidjan 09, Côte d'Ivoire
}

*Corresponding author

\begin{abstract}
A B S T R A C T

\begin{tabular}{|c|}
\hline Keywords \\
\hline $\begin{array}{l}\text { Comoe river, Escherichia } \\
\text { coli, Intestinal } \\
\text { enterococci, Microbial } \\
\text { pollution, Public health }\end{array}$ \\
\hline Article Info \\
\hline $\begin{array}{l}\text { Accepted: } \\
\text { 06 September } 2018 \\
\text { Available Online: } \\
\text { 10 October } 2018\end{array}$ \\
\hline
\end{tabular}

The microbial pollution caused by human activities exposes urban areas of the Comoe River to major health risks linked to any pathogens presence. This study aims to assess microbiological water quality using fecal indicators bacteria (FIB) in order to determine potential risk for the populations and understand FIBs' seasonal variability. From February 2015 to December 2016, 5 sampling campaigns were performed at 8 stations in the river (6) and tributaries (2). FIB abundances ranged between $1.09 \times 10^{3}$ and $8.88 \times 10^{4} \mathrm{E}$. coli $(100 \mathrm{ml})^{-1}$ and between $5.33 \times 10^{2}$ and $4.49 \times 10^{3} \mathrm{IE}(100 \mathrm{ml})^{-1}$ in river. They varied between $1.06 \times 10^{3}$ and $1.58 \times 10^{3} \mathrm{E}$. coli $(100 \mathrm{ml})^{-1}$ and between $5.00 \times 10^{2}$ and $7.09 \times$ $10^{2} \mathrm{IE}(100 \mathrm{ml})^{-1}$ in the tributaries. Based on the FIB abundance, the river presents a poor microbiological water quality for recreational and domestic activities. The concentrations observed in the river water are affected by climatic seasons with most important concentration observed during dry season. Dilution effect from tributaries waters may explain this variability. A monitoring program must be implemented to control water quality during the seasons.
\end{abstract}

\section{Introduction}

Surface waters, including rivers and streams represent an important source of water for drinking, household, agriculture, recreational activities and other uses. However, they are vulnerable to pollution and frequently contaminated with faeces (Kolarević et al., 2011). The direct or indirect contamination of the aquatic environment by human and animal faeces generates high levels of enteric microorganisms that lead to the deterioration of the microbiological quality. Among the enteric microorganisms (bacteria, viruses, parasitic protozoa), some are pathogenic for humans (García-Armisen, 2007; Sibanda et al., 2013) and then may induce water-related and waterborne diseases. 
In aquatic environments, the detection of all potential pathogens is very difficult and uncertain because of the great diversity of pathogenic microorganisms that may be present in the water, the low abundance of each pathogenic species of hence the need for concentrate very large volumes of water to detect them, the lack of standardized and fast methods for the detection of all these pathogenic microorganisms (Ouattara et al., 2013). Consequently, the microbiological quality assessment of waters is based on contamination indicators which do not necessarily have a pathogenic character (Ahmed et al., 2006; Sibanda et al., 2013). However, their presence in the water indicates the existence of a contamination by faeces, which could have harmful effects on public health (Abdelzaher, 2010). So their abundance is an indication of the level of risk of pathogenic microorganisms presence such as Salmonella spp., Shigella spp. Vibrio sp., Pseudomonas aeruginosa and enteric viruses (Ouattara et al., 2013; 2014) in both tropical and temperate systems (Pachepsky et al., 2011).

The works of the WHO (2003), European Union Directive (2006) and NHMRC (2008) showed that intestinal enterococci (EI) and $E$. coli are the best indicators of the health risk associated with the various uses of water. A short review of literature showed that these indicators are used around the word to evaluate the microbiological water quality of surface waters (NPS-FWM, 2014). The use of faecal indicators bacteria (FIB) in the evaluation of the microbiological quality of surface and underground waters is widely criticized in the literature considering the lack of correlation between abundance of $E$. coli and IE and the abundance of certain viruses and protozoans in aquatic environments (Hörman et al., 2004) and a repercussion of the disease in swimmers (Haile et al., 1999a). Furthermore, these groups of bacteria can come from a variety of sources, among others warm-blooded animals (Servais et al., 2009a) and waters rich in organic matter (Santé Canada, 2012). Despite these criticisms, sometimes very objective, they remain the only indicators used in all international standards and directives in the world for the monitoring of microbiological quality of surface waters (Servais et al., 2009a).

The fecal pollution of waters is considered as a risk of public health and remains a concern with regard to coliform concentrations enumerated in the water (European Union Directive, 2006).

Therefore, considering anthropogenic activities result in a significant decrease in surface water quality of aquatic systems in watersheds and the FIB abundances in waters that give information of public health, having an understanding of the spatial distribution and temporal variability of the FIB responsible for certain diseases is essential. Furthermore, understanding the factors that control the relationship between abundance of FIB and physic and chemical parameters is a prerequisite for reducing human health risks associated with the use of unclean water.

The Comoe River, located in an area subject to intense agricultural activities, urbanization combined to the population growth, is used for fishing, bathing but also for laundry, the dishes and sometimes used as drinking water by the local populations. The Comoe River receives water of Aghien and Potou lagoons located in the upstream part. It also receives all the microbial pollution drained by these waters. The paucity of data on microbiological quality as well as the potential sources of faecal contamination of the river's waters limits the implementation of adequate measures to protect the river. The assessment of faecal contamination of the water Comoe River and its main tributaries may lead toward 
a good ecological functioning of this environment and also guaranteer the sustainability of economic activities and populations' health. The study aims to i) evaluate the level of fecal microbial pollution in the river and its tributaries using E. coli and intestinal enterococci as faecal indicators bacteria and ii) determine the influence of FIBs' seasonal variability in the river.

\section{Materials and Methods}

\section{Study area}

The downstream part of Comoe River is included in the wetland of Grand Bassam which, itself, is located in the southeastern of Côte d'Ivoire (Yaokokoré-Béibro et al., 2005). The whole watershed of Comoe covers a surface of about $78000 \mathrm{~km}^{2}$ among which 57 $000 \mathrm{~km}^{2}$ in Côte d'Ivoire (Girard et al., 1971). The watershed of the Comoe River is composed by two main sub-basins: Kodjoboue and Ono. The sub-basins Kodjoboue and Ono are respectively crossed, by a lake and a lagoon which bears its name. The Kodjoboue Lake $\left(3.404 \mathrm{~km}^{2}\right.$ area) communicates with the Comoe River by a trickle of water (Brou, 1997). The Ono lagoon ( $4 \mathrm{~km}^{2}$ area), is a small ecosystem located at the extreme east of the lagoon complex Ebrié. The watershed of this lagoon is composed by rural area and industrial crops area and industrial agroindustrial production unit. Then, the Ono lagoon receives sewage waters from industrial units, surface run off of crops and domestic waters from rural area (Table 1). The river also receives waters from the Ono lagoon, Kodjoboue Lake and the Potou lagoon, itself fed with Bété and Djibi rivers.

The figure 1 represents the map taking into account the sampling longitudinal profile of waters Comoe River and its main tributaries and the table 1 illustrates the characteristics of each sampling station.

\section{Sampling and analysis methodology}

The water samples were taken from the Comoe River and its tributaries from February 2015 to December 2016. During five (5) sampling campaigns ( 3 in dry season and 2 in rainy season) a total of 40 samples were collected at eight (8) stations in the Comoe River (6) and in its tributaries (2). Water collections were performed following the sampling method proposed by Rodier et al., (2009) and recommendations of Standards Methods, 2005. Briefly, sterile bottles of $1 \mathrm{~L}$ were filled out with water sampled at $30 \mathrm{~cm}$ from the surface. Bottle were stored at $4{ }^{\circ} \mathrm{C}$ and transported in the laboratory of environment and biological aquatic from Nangui Abrogoua University (Abidjan, Côte d'Ivoire) for microbiological analysis.

\section{Physicochemical parameters analyzed}

A total of 3 physic and chemical parameters were measured to evaluate waters quality. Temperature, dissolved oxygen and $\mathrm{pH}$ were determined in situ using HACH LANGE Specific probes and HQ 40d multimeter. For the various measures, the respective probes of these devices were immersed in the water at each station as recommended by supplier. The used methods are the ones quoted by Rodier et al., (2009). The results of the physic and chemical parameters were expressed on average, minimum then maximum and indicated in the table 2 .

\section{Enumeration of $E$. coli and intestinal enterococci by culture based methods}

E. coli and IE were enumerated in water samples by standard plate counts respectively on Tryptone Bile X Glucuronide (TBX) (BioRad, France) and Slanetz and Bartley Agar (CONDA, Spain) with TTC (triphenyltetrazolium chloride) (0.2\%) incorporated (Standard Methods, 2005). These 
two chromogenic growth media were shown to be highly specific to their corresponding indicator bacteria (ISO 7899-2 (08/2000) and ISO 16649-2: 2001). For the detection of $E$. coli and IE, $100 \mu \mathrm{L}$ of the water sample was plated or spread one or more successive decimal dilutions thereof directly on Slanetz and Bartley agar (CONDA, Spain) when a high concentration of fecal bacteria is presumed.

Also the filtration of a very precise volume of the sample $(1 \mathrm{~mL}, 10 \mathrm{~mL}$ or $100 \mathrm{~mL})$ on a sterile filter membrane (porosity $0.45 \mu \mathrm{m}$ and pore diameter $47 \mathrm{~mm}$ ) was carried out for lower expected concentrations in bacteria and the filter was gently deposited on the agar.

For $1 \mathrm{~mL}$ of sample, a sufficient volume of sterile Ringer's solution was added to the funnel to obtain a good distribution of bacteria over the entire filter surface. Slanetz and Bartley supplemented with TTC plates were incubated at $36{ }^{\circ} \mathrm{C}$ for $44 \mathrm{~h}$ then at $44{ }^{\circ} \mathrm{C}$ for 2 $\mathrm{h}$ and TBX plates were incubated at $37^{\circ} \mathrm{C}$ for $24 \mathrm{~h}$ before enumeration. Plate counts were expressed as colony forming units (CFU) per $100 \mathrm{~mL}$ of sample. Subsequently, on the agar plates, the suspect colonies of E. coli and IE appearing respectively blue and purple or pink or red to brown were enumerated and the results were summed and expressed in colony forming unit (CFU) to obtain the concentration per $100 \mathrm{~mL}$ of sample.

\section{Statistical analysis}

All data were submitted to descriptive methods used to synthesize the results of the assessment of the level of faecal pollution and trends in terms of seasonal variations. Some observed trends were verified by the nonparametric Mann-Whitney test. Tables and charts were achieved with Excel software but hypothesis tests, means and ranges were implemented using the R software.

\section{Results and Discussion}

Physical and chemical characteristics of Comoe River and its tributaries

A summary of the physical and chemical characteristics of the river and its tributaries are presented in table 2 . The $\mathrm{pH}$ mean values vary between 6.85 and 7.14 in the river and then between 6.09 and 6.79 in the tributaries. The water has a relatively neutral $\mathrm{pH}$ during the sampling period. The $\mathrm{pH}$ of the river's waters is characterized by higher values at the Moossou station (7.85) and lower values at the Pepiniere station (6.49). In the tributaries, the maximum (7.5) and minimum (5.19) values were recorded particularly at the Kodjoboue Embouchure station showing an important variation of the $\mathrm{pH}$ values.

The temperature values varied between 28.60 ${ }^{\circ} \mathrm{C}$ and $29.95{ }^{\circ} \mathrm{C}$ in the Comoe River with high level value at downstream M.: $\left(32.3{ }^{\circ} \mathrm{C}\right)$ and lower value at Moossou station $\left(26.8{ }^{\circ} \mathrm{C}\right)$. The temperature values in the tributaries varied between $28.38{ }^{\circ} \mathrm{C}$ and $30.15{ }^{\circ} \mathrm{C}$ with maximum value at Ono-Salci Embouchure $\left(32.4{ }^{\circ} \mathrm{C}\right)$ and minimum value at Kodjoboue Embouchure $\left(25.9{ }^{\circ} \mathrm{C}\right)$. The Average dissolved oxygen concentrations decreases from upstream to downstream of the river. The oxygen content values ranged from $0.45 \mathrm{mg} / \mathrm{L}$ (Pepiniere station) to $10.11 \mathrm{mg} / \mathrm{L}$ (M. Amont) with highly specific variation in each station and from one station to another one. In the tributaries, the concentrations of dissolved oxygen varied from $0.1 \mathrm{mg} / \mathrm{L}$ to $6.4 \mathrm{mg} / \mathrm{L}$.

\section{$E$. coli and intestinal enterococci in the Comoe River and its tributaries}

Abundance of $E$. coli and intestinal enterococci in the waters of the Comoe River

The analysis of our results (Figure 2 ) shows a great variability of the microbial pollution 
(concentrations between $1.09 \times 10^{3}$ and $8.88 \times$ $10^{4}$ E. coli $(100 \mathrm{ml})^{-1}$ then $5.33 \times 10^{2}$ and 4.49 $\left.\times 10^{3} \mathrm{IE}(100 \mathrm{ml})^{-1}\right)$ in the river. However, the mean abundances of faecal contamination indicators are $2.13 \times 10^{4} \mathrm{E}$. coli $(100 \mathrm{ml})^{-1}$ and $1.80 \times 10^{3} \mathrm{IE}(100 \mathrm{ml})^{-1}$.

The highest concentrations were measured at the Pepiniere Station for E. coli and at the Yaou Station for intestinal enterococci. The lowest concentrations were observed at the station at Moossou for E. coli and at the upstream M. station for intestinal enterococci. However, concentrations of E. coli were higher altogether.

Abundance of $E$. coli and intestinal enterococci in the main tributaries of the Comoe River

The figure 3 represents the concentration $\mathrm{f}$ fecal indicators in the main tributaries of the Comoe River.

The results show a low concentration of microbial pollution with microbial abundances between $1.06 \times 10^{3}$ and $1.58 \times 10^{3}$ E. coli $(100$ $\mathrm{ml})^{-1}$ then $5.00 \times 10^{2}$ and $7.09 \times 10^{2}$ IE $(100$ $\mathrm{ml})^{-1}$ in tributaries. However, the mean abundances of fecal contamination indicators are $1.06 \times 10^{3}$ E. coli $(100 \mathrm{ml})^{-1}$ and $7.09 \times$ $10^{2}$ IE $(100 \mathrm{ml})^{-1}$ in the Ono lagoon while those obtained in Kodjoboue lake are $1.5 \times$ $10^{3}$ E. coli $(100 \mathrm{ml})^{-1}$ and $5.00 \times 10^{2} \mathrm{IE}(100$ $\mathrm{ml})^{-1}$. On all sampling stations, concentrations of $E$. coli were higher than those of intestinal enterococci.

Seasonal variations of the abundance of fecal indicators bacteria in the Comoe River

The figure 4 states the seasonal variations of faecal indicators bacteria at the different stations in the Comoe River. The analysis of our results (Figure 4a) shows a low abundance of $E$. coli in the rainy season (RS) while in the dry season (DS), this abundance is much higher. At the threshold $\alpha=5 \%$, the $p$-value calculated with $\mathrm{R}$ was 0.26 . The Mann Whitney test $(\mathrm{p}>0.05)$ reveals no significant difference between $E$. coli and the seasons.

Concerning intestinal enterococci (Figure 4b), a much lower rate is recorded in the DS while this abundance is much higher in the RS. At the threshold $\alpha=5 \%$, the p-value calculated with R was 0.44 . The Mann Whitney test ( $p$ > $0.05)$ revealed no significant difference between intestinal enterococci abundance and the seasons.

\section{Abundance of faecal indicators bacteria in surface waters: comparison between abundance of $E$. coli and intestinal enterococci in tropical fluvial environments}

The mean concentration of microbial pollution obtained in Comoe River waters are $1.06 \times$ $10^{3}$ E. coli $(100 \mathrm{ml})^{-1}$ and $7.09 \times 10^{2} \mathrm{IE}(100$ $\mathrm{ml})^{-1}$ in the Ono lagoon and in the order of $1.58 \times 10^{3}$ E. coli $(100 \mathrm{ml})^{-1}$ and $5.00 \times 10^{2} \mathrm{IE}$ $(100 \mathrm{ml})^{-1}$ in Kodjoboue lake.

The presence and the abundance of faecal indicators bacteria in waters of the river show that waters of tributaries are directly drained directly in comoe. The longitudinal profile of waters of the downstream part of Comoe River shows that mean abundance of $E$. coli exceeds the bathing water quality standard (European Union Directive, 2006).

The abundances of intestinal enterococci observed in waters of the river are higher than those recommended by international standards for the microbiological quality of water. International guidelines recommended use of E. coli and enterococci as indicators of fecal contamination of recreational waters even if the quality standards vary according to countries in terms of abundance. However, these guidelines did not indicate if it necessary to consider that the microbiological quality of 
the water is acceptable for recreational activities when one of the two criteria is respected.

The faecal contamination levels observed in the waters of the downstream part of Comoe River are similar to those met in the surface waters of several cities in Africa. For example, Musyoki et al., (2013) which realized a study in Nairobi River, crossing the capital Nairobi of Kenya and its tributary (Athi River), showed that the abundances of fecal indicators bacteria in waters of the rivers were of $1.0 \times$ $10^{4}$ E. coli $\left(100 \mathrm{ml}^{-1}\right.$ and $3.6 \times 10^{3}$ Enterococcus faecalis $(100 \mathrm{ml})^{-1}$. Sibanda et al., (2013) estimated the distribution of faecal indicators bacteria in Tyume River in the Eastern Cape Province, in South Africa. The faecal coliform (including $E$. coli) enumerated ranged from $1.0 \times 10^{2}$ to $1.6 \times 10^{4} \mathrm{CFU}(100$ $\mathrm{ml})^{-1}$ while enterococci counts were of the order of $3.3 \times 10^{1}$ to $5.1 \times 10^{3} \mathrm{CFU}(100 \mathrm{ml})^{-1}$. Particularly, we were surprise by the fact that abundances of fecal contamination in these surface waters were lower than the value observed in the outlet of wastewater treatment plants in Europe (Ouattara et al., 2014). On the Basis of the data of $E$. coli and intestinal enterococci abundances observed in surface waters of several urban areas, it seems that the abundances of these fecal indicators bacteria are relatively low considering the lack of sanitation systems in the urban area in developing countries.

We also observed that in the majority of sampling stations, the abundances of E. coli were higher than those of intestinal enterococci. Stations situated upstream and downstream of Motobe, to Yaou and Pepiniere present the peculiarity of a degradation stressed of the microbiological quality further to the pourings and rejections of diverse and varied origins (domestic rejections, industrial discharges, etc). According to the literature, the abundance of $E$. coli measured in waters (wastewaters and surface waters) is higher, for the most part of the time, than that of intestinal enterococci. Our results corroborate those reported by Ouattara et al., $(2011 ; 2014)$ in the case of wastewater in Belgium. They could give some explanation by the fact that this zone is impacted by the immense industrial and rustic plantations and its microbiological quality or already altered upstream (M. Amont and M. Aval stations) of the downstream part of Comoe River. This deterioration could result from the activities of housing environments by the poor agricultural practices, from fishing and poaching which establish a serious threat to the area. According to Passerat et al., (2011), this degradation in microbiological quality can be due to the resuspension of sediments in the bed of the river because of to the increase of the flow or the increase of runoff of rural areas due to the rainy event.

Concerning of surface waters, several authors also showed that the abundance of E. coli is higher than that of intestinal enterococci. For example, Passerat et al., (2011) observed in the Seine river that the abundance of $E$. coli $\left(1.5 \times 10^{6}(100 \mathrm{ml})^{-1}\right)$ was three times that of intestinal enterococci $\left(4.0 \times 10^{5}(100 \mathrm{ml})^{-1}\right)$. Furthermore, a good correlation between these two indicators (E. coli and intestinal enterococci) was demonstrated (Farnleitner et al., 2010, Ouattara et al., 2014). But in this study, a bad correlation was found $(\mathrm{R} 2=$ $0.0384 ; n=40)$. An answer possible for the bad correlation observed in the downstream part of Comoe River and its tributaries would be due to specific and intrinsic factors in the study area. The abundances of fecal indicators bacteria observed in the downstream part of Comoe River and its tributaries show of the fact that they received wastewater coming directly from domestic and industrial discharges. In aquatic environments, studies demonstrated that the IE is more resistant than E. coli (Medema et al., 1997, Craig et al., 2002b). 
Table.1 Characteristics of the sampling stations along Comoe River and its tributaries

\begin{tabular}{|c|c|c|c|c|c|c|}
\hline \multirow[t]{2}{*}{$\begin{array}{l}\text { Sampling } \\
\text { sites }\end{array}$} & \multirow[t]{2}{*}{ Code } & \multicolumn{2}{|c|}{$\begin{array}{c}\text { Geographical } \\
\text { positions (UTM) }\end{array}$} & \multirow[t]{2}{*}{ Land use } & \multirow[t]{2}{*}{ Substratum (\%) } & \multirow[t]{2}{*}{$\begin{array}{c}\text { Canops } \\
(\%)\end{array}$} \\
\hline & & $\mathbf{X}$ & $\mathbf{Y}$ & & & \\
\hline $\begin{array}{l}\text { Motobe } \\
\text { amont }\end{array}$ & S1 & 428583 & 591025 & $\begin{array}{l}\text { Cocoa, rubber tree and } \\
\text { banana plantations }\end{array}$ & \multirow{2}{*}{$\begin{array}{l}\text { Mud }(45 \%) \\
\text { Clay-silt }(50 \%) \\
\text { Plant debris }(5 \%)\end{array}$} & \multirow[t]{2}{*}{5} \\
\hline Motobé aval & S2 & 429627 & 587802 & $\begin{array}{l}\text { Village, cocoa and } \\
\text { rubber tree plantations }\end{array}$ & & \\
\hline Yaou & S3 & 427885 & 581346 & $\begin{array}{l}\text { Village, garbage dump, } \\
\text { cocoa and rubber tree } \\
\text { plantations }\end{array}$ & $\begin{array}{l}\text { Sand }(15 \%) \\
\text { Clay-silt }(20 \%) \\
\text { Mud }(60 \%)\end{array}$ & 0 \\
\hline $\begin{array}{l}\text { Kodjoboue } \\
\text { Embouchure }\end{array}$ & S4 & 429120 & 580616 & Rubber tree plantations & $\begin{array}{l}\text { Sand }(35 \%) \\
\text { Plant debris }(40 \%) \\
\text { Mud }(25 \%)\end{array}$ & 70 \\
\hline $\begin{array}{l}\text { Pepiniere } \\
\text { Palmci }\end{array}$ & S5 & 429627 & 579802 & $\begin{array}{l}\text { Housing, palm nurseries } \\
\text { and cocoa plantations }\end{array}$ & $\begin{array}{l}\text { Mud }(80 \%) \\
\text { Sand }(20 \%)\end{array}$ & 0 \\
\hline Adjekro & S6 & 425485 & 578414 & $\begin{array}{l}\text { Housing, organic } \\
\text { fertilizer plant, pigsty, } \\
\text { rubber tree and coconut } \\
\text { plantations }\end{array}$ & $\begin{array}{l}\text { Sand }(15 \%) \\
\text { Mud }(50 \%) \\
\text { Argile-limon } \\
(40 \%)\end{array}$ & 0 \\
\hline Moossou & S7 & 420776 & 576660 & Bridge, vegetable crops & $\begin{array}{l}\text { Mud }(80 \%) \\
\text { Clay-silt }(20 \%)\end{array}$ & 0 \\
\hline $\begin{array}{l}\text { Ono } \\
\text { Embouchure }\end{array}$ & S8 & 431501 & 585658 & $\begin{array}{l}\text { Cocoa, rubber tree, } \\
\text { palm nurseries, banana } \\
\text { and pineapple } \\
\text { plantations }\end{array}$ & $\begin{array}{l}\text { Sand } \\
\text { Plant debris }\end{array}$ & 0 \\
\hline
\end{tabular}

Table.2 Physical and chemical parameters (expressed in mean, minimum and maximum values observed during the sampling campaigns) measured in the Comoe River and its main tributaries

\begin{tabular}{|l|c|c|c|}
\hline \multirow{2}{*}{ Sampling sites } & \multicolumn{3}{|c|}{ Physicochemical parameters studied } \\
\hline M. Amont & $\mathrm{pH}$ & $\mathrm{T}\left({ }^{\circ} \mathrm{C}\right)$ & $\mathrm{O}_{2}(\mathrm{mg} / \mathrm{L})$ \\
\hline M. Aval & $7.01(6.64-7.6)$ & $29.95(27.3-32.3)$ & $6.23(0.99-$ \\
& & & $10.11)$ \\
\hline Yaou & $7.10(6.65-7.7)$ & $29.34(27.1-33)$ & $6.04(2.04-8.11)$ \\
\hline Pepiniere & $6.85(6.5-7.3)$ & $29.09(27.2-32.6)$ & $4.97(2.14-7.73)$ \\
\hline Adjekro & $6.98(6.49-$ & $28.87(27-31.1)$ & $2.99(0.45-5.7)$ \\
\hline Moossou & $7.46)$ & & \\
\hline Ono - Salci Embouchure & $7.09(6.57-7.4)$ & $28.83(27.1-32.3)$ & $4.38(1.01-7.12)$ \\
\hline Kodjoboue Embouchure & $6.14(6.67-$ & $28.60(26.8-31.1)$ & $4.47(1-8.98)$ \\
\hline
\end{tabular}


Fig.1 Map showing the longitudinal profile of downtream part of Comoe River and its main tributaries (Ono lagoon and Kodjoboue lake)

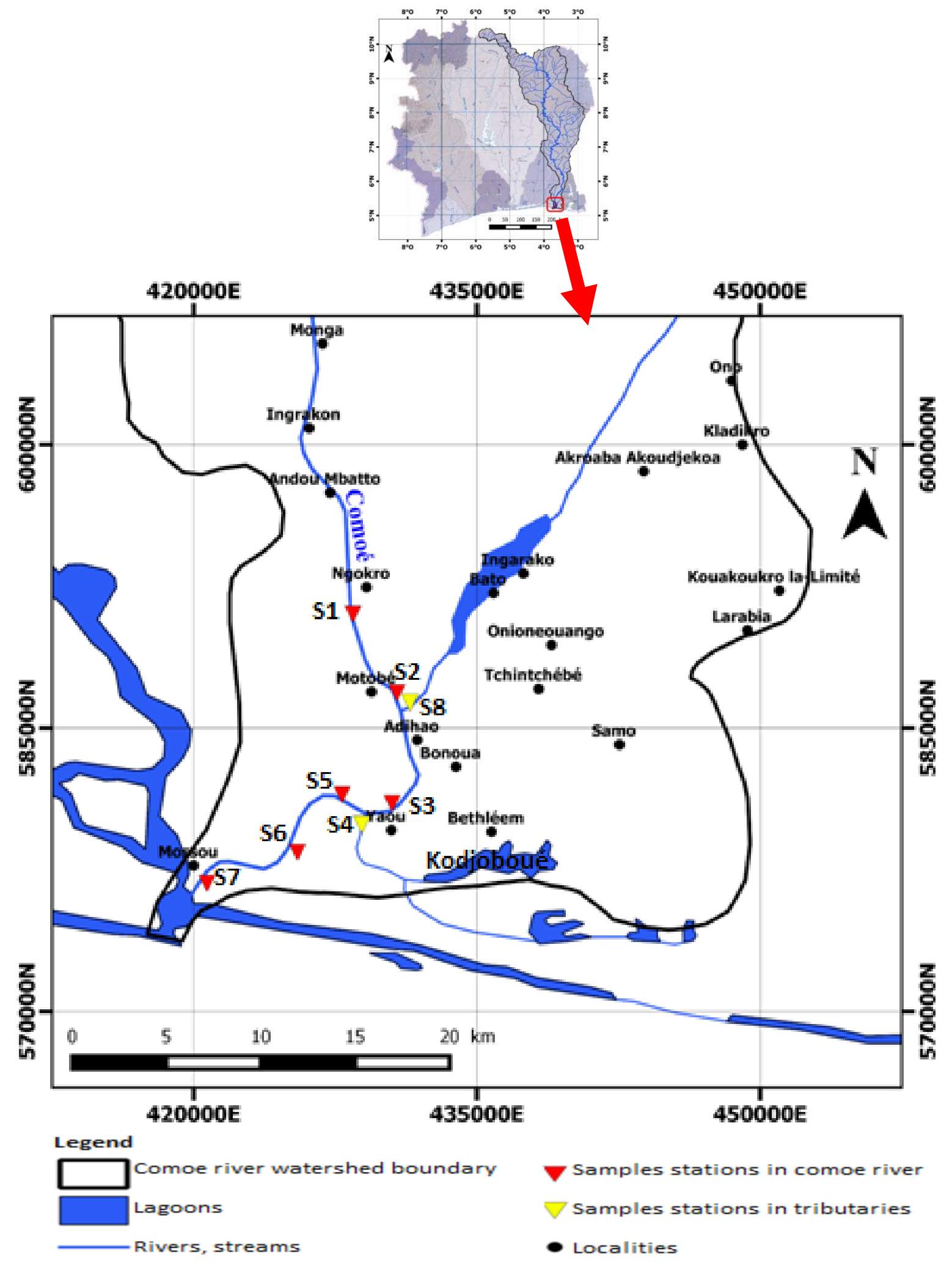


Fig.2 Concentrations of fecal bacteria in the Comoe River. The data are expressed in geometric mean and the vertical bars represent the intervals between the minimum and maximum values

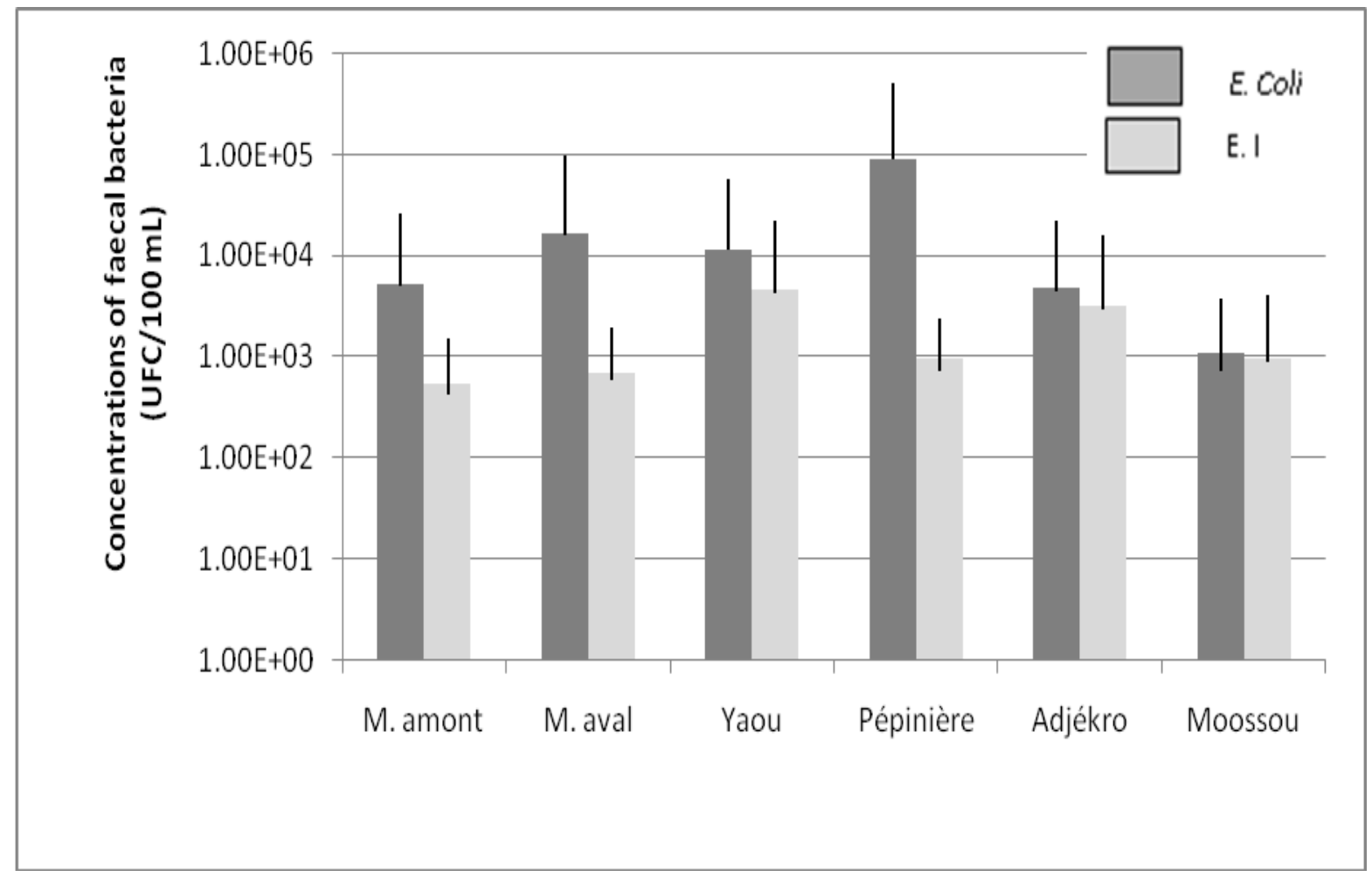

Fig.3 Concentrations of fecal bacteria in the main tributaries of the Comoe River. The data are expressed in geometric means and the vertical bars represent the intervals between the minimum and maximum values

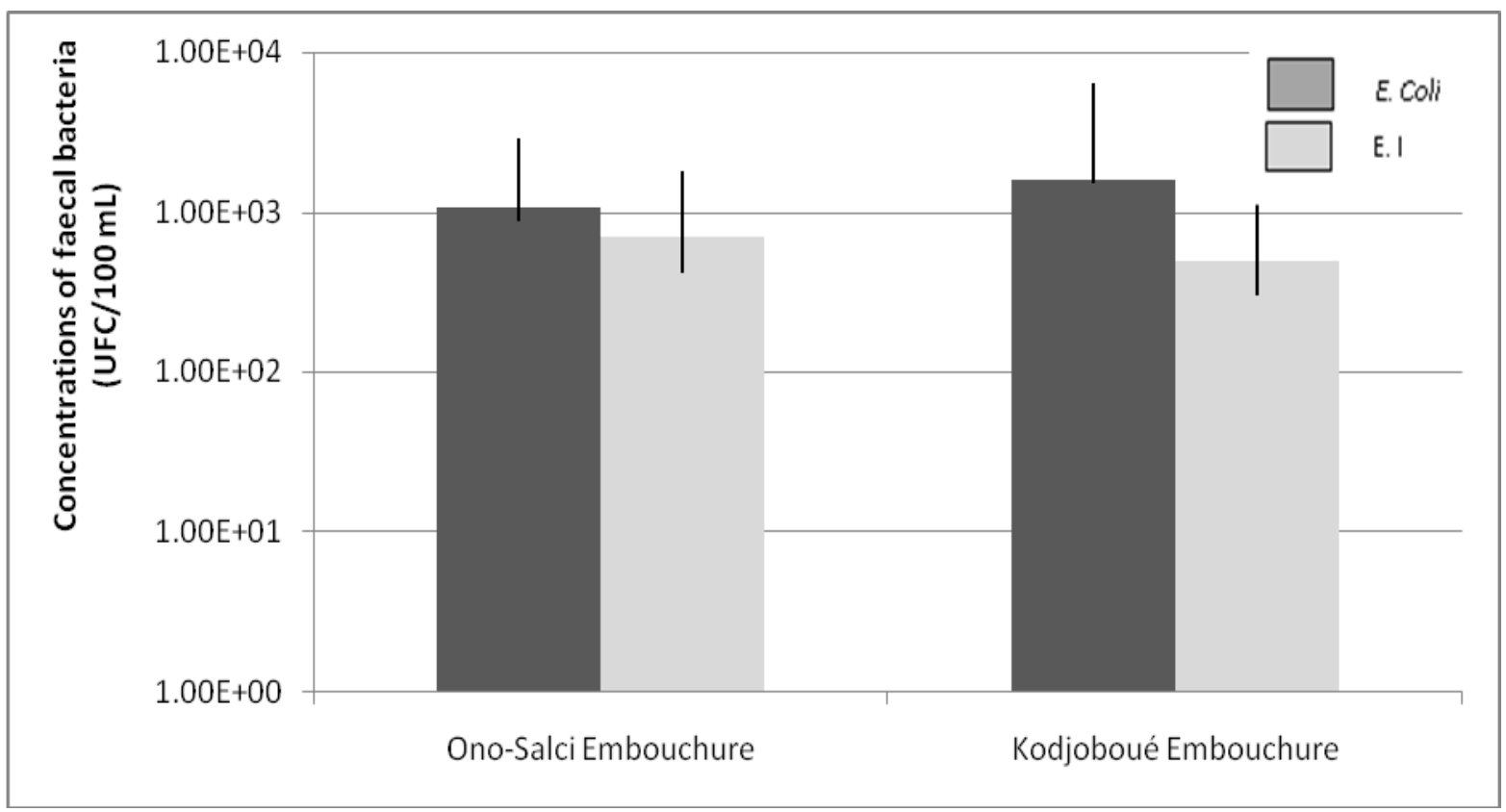


Fig.4 Box plots (in Log units) showing seasonal variations in fecal contamination level in the Comoe River $\left(\mathrm{a}=\log \mathrm{EC}\left(\mathrm{CFU}(100 \mathrm{~mL})^{-1}\right), \mathrm{b}=\log \mathrm{EI}\left(\mathrm{CFU}(100 \mathrm{~mL})^{-1}\right), \mathrm{RS}=\right.$ rainy season and DS $=$ dry season)

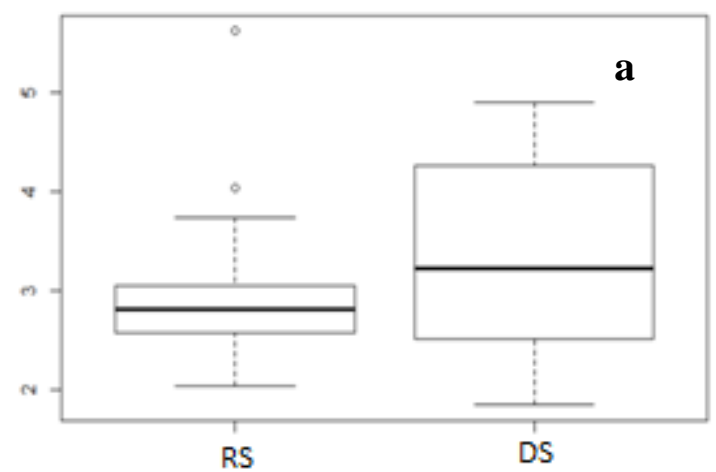

The abundance of $E$. coli would indicate a recent faecal contamination whereas the abundance of the IE would indicate an older faecal contamination.

Influence of the state of tributaries on the quality of water of the Comoe River: comparison between fecal bacteria abundances in the river and the Ono and Kodjoboue watersheds

The abundances of fecal indicators bacteria in the Comoe River and tributaries showed a relatively abundances of $E$. coli in the tributaries compared with that in the river. Altogether, the Comoe River presents highest abundances of contamination in terms of fecal bacteria and Kodjoboue lake, the lower with the Ono lagoon which presents a moderately high abundance of contamination. The Mann Whitney test shows that there is no significant difference between the abundance of contamination in terms of fecal pollution by $E$. coli in the river and its tributaries. It means that the level of $E$. coli contamination in the tributaries is the same those in stations at the level of the river $(\mathrm{p}>0.05)$. In other words, the major part of the faecal contamination would result from tributaries, even from $E$. coli. As regards the intestinal enterococci, the faecal pollution is practically identical in the Ono lagoon and Kodjoboue lake. On the other

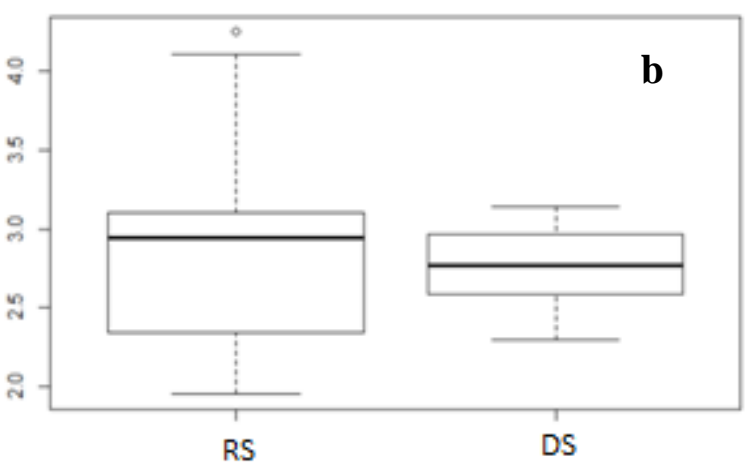

hand, the level of pollution in the river is very variable. The Mann - Whitney test used also shows that there is no significant difference between the level of faecal pollution by intestinal enterococci in the river and its tributaries. It means that the level of contamination of intestinal enterococci in the tributaries is the same than that in river stations $(p>0.05)$. This result could give some explanation by the fact that tributaries would be inhibited in terms of faecal pollution or the downstream part of Comoe River would have a low level of faecal contamination.

On all the results obtained in tributaries, the level of pollution in the Ono lagoon is higher than that in Kodjoboue lake in terms of fecal contamination indicators. At the same time, the Mann-Whitney test made to estimate the difference between the FIB concentrations in the lagoon and the lake at the pollution of the Comoe River indicates that Ono's FIB concentration to Kodjoboue is not significant $(\mathrm{p}>0.05)$ by taking into account the abundance of fecal pollution ( $E$. coli and intestinal enterococci). However, the longitudinal profile of the waters of the downstream part of Comoe River and its tributaries show average abundance above the bathing water quality standard (European Union Directive, 2006). The Ono lagoon 
situated downstream of Motobe present the peculiarity of a degradation stressed of the microbiological quality further to the pourings and the rejections of diverse and varied origins (domestic rejections, industrial discharges, etc.).

The relationship between population and the microbiological quality of water can be a good indicator to explain the difference between microbial pollution of the hydrosystems receiving pollution from their respective populations. This relation is a particular indication in the absence of a sanitation system, especially in the sub-basins (Ono and Kodjoboue) that are the object of comparison in our study. The highest abundance of fecal bacteria observed in the Ono lagoon could find its explanation by this factor underlined above. According to Chigor et al., (2013), it could also be attributable to anthropogenic activities and the increase of populations in the different watersheds.

The results presented in this study are in agreement with those indicated by Hunter (2003) and Chigor et al., (2012) that rainy seasons can lead to high abundances in fecal indicators bacteria in river waters and suggest that populations bathing in the Buffalo River are confronted with a greater risk of disease.

According to the United States Environmental Protection Agency (USEPA), recreational waters with concentrations exceeding the maximum limit of 33 or $200 \mathrm{CFU}(100 \mathrm{ml})^{-1}$ for enterococci (IE) or faecal coliform (FC) respectively exhibit health risk (USEPA, 1986; Abdelzaher et al., 2010).

The South Africa Department of Water Affairs (SA-DWAF) sets the required water quality range for both parameters between 0 $30 \mathrm{CFU}(100 \mathrm{ml})^{-1}$ for IE and 0-130 CFU $\left(100 \mathrm{ml}^{-1}\right.$ for FC (DWAF, 1996b). The percentage of water samples in this study that exceeded these limits is $100 \%$ for faecal coliform and intestinal enterococci. At Parkside, where recreational activities are most pronounced on the Buffalo River, unacceptable levels of intestinal enterococci were observed in $92-100 \%$ of the water samples.

This work carried out in the downstream part of Comoe River enabled to evaluate the state of seasonal pollution coupled with the enumeration of the faecal contamination indicators of the area as well as their relationship with the environmental variables.

The increase of faecal indicators bacteria abundance resulting from the river including its main tributaries reveals the danger to local populations and human activities. Our results indicate that the bacteriological quality of the Comoe River and the tributaries are not sufficient limiting their uses for domestic and recreational activities, so that are therefore significant risks to public health.

The future researches should focus on assessing the quality of these surface waters by the presence of pathogenic bacteria and viruses of public health interest. The supplying of adequate sanitation facilities will help prevent the source of river water contamination and public health education to improve personal and community hygiene is a requirement.

\section{Acknowledgments}

This work was done as part of a project of research entitled «Approche écosystémique de la pêche comme moyen d'exploitation durable des ressources halieutiques dans la zone humide de Grand-Bassam » (Ecosystem approach to fisheries as a means of sustainable exploitation of fisheries resources in the Grand-Bassam wetland). This project benefited from the funding of the PASRES 
(Strategic Support Program Scientific Research of the Swiss Center for Scientific Research in (CSRS) (Côte d'Ivoire), project No 110 - 2014-2016) of the Ivorian Ministry of Higher Education and Research the scientific research.

\section{References}

Abdelzaher, A.M., M.E. Wright., C. Ortega, H.M. Solo-Gabriele, G. Miller, S. Elmir, X. Newman, J.A. Bonilla and Bonilla, T.D. et al., 2010. Presence of pathogens and indicator microbes at a non-point source subtropical recreational marine beach. Appl Environ Microbiol 76:724-732.

Ahmed, W., R. Neller and Katouli, M. 2006. Population similarity of enterococci and Escherichia coli in surface waters: a predictive tool to trace the sources of faecal contamination. J Water Health doi: 10.2166/ wh.2006.042.

Brou, Y. 1997. Analyse et dynamique de la pluviométrie en milieu forestier ivoirien. Thèse de Doctorat 3ème cycle. Université de Cocody Abidjan, Côte d'Ivoire : $200 \mathrm{p}$.

Chigor, V.N., T. Sibanda and Okoh, A.I. 2013. Studies on the bacteriological qualities of the Buffalo River and three source water dams along its course in the Eastern Cape Province of South Africa. Environ Sci Pollut Res, 20: 4125-4136.

Chigor, V.N., V.J. Umoh, C.A. Okuofu, J.B. Ameh, E.O. Igbinosa and Okoh, A.I. 2012. Water quality assessment: surface water sources used for drinking and irrigation in Zaria, Nigeria are a public health hazard. Environ Monit Assess, 184: 3389-3400.

Craig, D.L., H.J. Fallowfield and Cromar, N.J. 2002b. Comparison of the decay rates of faecal indicator organisms in recreational coastal water and sediment. Water Sci Tech. 2 (3), 131-138.

Department of water affairs and forestry (DWAF), 1996b. South African water quality guidelines (2nd Edn.). Vol. 2: Recreational Use. Pretoria: Department of Water Affairs and Forestry.

European Union Directive, 2006. Directive 2006/7/EC of the European Parliament and of the Council of 15 February 2006 concerning the management of bathing water quality. $O \mathrm{~J}, 64: 37-51$.

Faby, J.A. and Celerier, J.L. 1998. Analyse des facteurs de dégradation de la qualité de l'eau dans les réseaux ; consignes et procédures pour les limiter; suivi de la qualité et modélisation, Ministère de 1'Agriculture et de la Pêche (MAP) Fonds National pour le Développement des Adductions d'Eaux rurales (FNDAE) - Office international de l'eau (OIEau), (12) : 1-98.

Farnleitner, A.H., G. Ryzinska-Paier, G.H. Reischer, M.M. Burtscher, S. Knetsch, A.K.T. Kirschner, T. Dirnböck, G. Kuschnig, R.L. Mach and Sommer, R. 2010. Escherichia coli and enterococci are sensitive and reliable indicators for human, livestock and wildlife faecal pollution in alpine mountainous water resources. J. Appl. Microbiol., 109 (5): 1599-1608.

García-Armisen, T. 2007. Etude de la dynamique des Escherichia coli dans les rivières du bassin de la Seine. Thèse présentée pour l'obtention du diplôme de Docteur en Sciences. Université Libre de Bruxelles, Belgique, Ecologie des Systèmes Aquatiques: p 173.

Girard, G., J. Sircoulon and Touchebeuf, P. 1971. Aperçu sur le régime hydrologique. In : Avenard J. M., Eldin M., Girard G., Sircoulon J., Touchebeuf P., Guillaumet J. L., Adjanohoun E. \& Perraud A. (éds.). Le milieu naturel de 
Côte d'Ivoire. Mémoire ORSTORM, Paris, 50 : 109-155.

Haile, R.W., J.S. Witte, M. Gold, R. Cressey, C. McGee and Millikan R.C. et al., 1999a. The health effects of swimming in ocean water contaminated by storm drain runoff. Epidemiology, 10 (1): 355363.

Hörman, A., R. Rimhanen-Finne, L. Maunula, C.-H. Von Bonsdorff, N. Torvela, A. Heikinheimo and Hanninen, M.-L. 2004. Campylobacter spp., Giardia spp., Cryptosporidium spp., Noroviruses, and indicator organisms in surface water in southwestern Finland, 2000-2001. Appl. Environ. Microbiol. 70, 87-95.

Hunter, P.R. 2003. Climate change and waterborne and vector-borne disease. $J$ Appl Microbiol, 94: 37S-46S.

Kolarević, S., J. Knežević-Vukčević, M. Paunović, Z. Gačić and Vuković-Gačić, B. 2011. Assessment of the microbiological quality of the River Tisa in Serbia. Water Res Manag, 1 (2): 57-61.

Medema, G.J., M. Bahar and Schets, F.M. 1997. Survival of cryptosporidium parvum, Escherichia coli, faecal enterococci and clostridium perfringens in river water: influence of temperature and autochthonous microorganisms. Water Sci. Tech. 35, 249-252.

Musyoki, A.M., M.A. Suleiman, J.N. Mbithi and Maingi, J.M. 2013. Water-borne bacterial pathogens in surface waters of nairobi river and health implication to communities downstream athi river. Int J Life Sci Pharma Res, 3 (1): 4-10.

NHMRC, 2008. Guidelines for managing risks in recreational water. National Health and Medical Research Council of Australia, Government of Australia, Canberra.

NPS FWM, National Policy Statement for Freshwater Management (New
Zealand), 2014. Microbiological water quality guidelines for recreational water.

Ouattara, K.N., J. Passerat and Servais, P. 2011. Faecal contamination of the water and sediment in the rivers of the Scheldt drainage network. Environ Monit Assess, 183: 243-257.

Ouattara, N.K., D.A. Brauwere, G. Billen and Servais, P. 2013. Modelling faecal contamination in the Scheldt drainage network. J. Marine Syst., 128: 77-88.

Ouattara, N.K., G.A. Tamara, A. Anzil, N. Brion and Servais, P. 2014. Impact of Wastewater Release on the Faecal Contamination of a Small Urban River: The Zenne River in Brussels (Belgium). Water Air and Soil Poll, 225 : 20432054.

Pachepsky, Y.A. and Shelton, D.R. 2011. Escherichia coli and Fecal Coliforms in freshwater and estuarine sediments. Crit. Rev. Env. Sci. Tech. 41, 10671110 doi: 10.1080/10643380903392718.

Passerat, J., N.K. Ouattara, J.M. Mouchel, V. Rocher and Servais, P. 2011. Impact of an intense combined sewer overflow event on the microbiological water quality of the Seine River. Water res., 45: 893-903.

Rochelle-Newall, E., T.M.H. Nguyen, T.P.Q. Le, O. Sengtaheuanghoung and Ribolzi, O. 2015. A short review of fecal indicator bacteria in tropical aquatic ecosystems: knowledge gaps and future directions. Front Microbiol, 6: 308-322.

Rodier, J., B. Legube, N. Merlet, R. Brunet, J.C. Mialocq, P. Leroy, M. Houssin, G. Lavison, C. Bechemin, M. Vincent, P. Rebouillon, L. Moulin, P. Chomodé, P. Dujardin, S. Gosselin, R. Seux and Al Mardini, F. 2009. L'analyse de l'eau $9^{\text {ème }}$ édition: $1579 \mathrm{p}$.

Santé Canada, 2012. Recommandations au sujet de la qualité des eaux utilisées à 
des fins récréatives au Canada, troisième édition. www.hc-sc.gc.

Servais, P., G. Billen, T. Garcia-Armisen, I. George, A. Goncalves and Thibert, S. 2009a. Identification of human fecal pollution sources in a coastal area: A case study at Oostende (Belgium). $J$ Water Health, 4 (2): 167-175.

Sibanda, T., V.N. Chigor and Okoh, A.I. 2013. Seasonal and spatio-temporal distribution of faecal-indicator bacteria in Tyume River in the Eastern Cape Province, South Africa. Environ Monit Assess, 185: 6579-6590.

Standard Methods, 2005. Standard methods for the examination of water and wastewater $\left(20^{\text {th }}\right.$ ed.). Washington DC:
American Public Health Association (APHA).

United States Environmental Protection Agency (USEPA), 1986. Ambient water quality criteria for bacteria. EPA440/584-002, U.S. Environmental Protection Agency Office of Water. Washington, DC.

WHO, 2003. Guidelines for safe recreational water environments. Vol. 1. Coastal and fresh waters. Organisation mondiale de la santé, Genève, Suisse. Disponible à:http://whqlibdoc.who.int/publications/ 2003/9241545801.pdf.

Yaokokoré-Béibro, K.H. and N'Douba, V. 2005. Fiche descriptive sur les zones humides Ramsar (FDR): 17 p.

\section{How to cite this article:}

Kouamé Cyr-Kevin Yao, Ouattara Koffi Nouho, Achiépo Odilon Yapo Mélaine and Ouattara Allassane. 2018. Impact and Seasonal Variability of Faecal Indicators Bacteria Contamination in Downstream Part of Comoe River and Its Two Tributaries (Côte d'Ivoire). Int.J.Curr.Microbiol.App.Sci. 7(10): 827-840. doi: https://doi.org/10.20546/ijcmas.2018.710.091 